\title{
Soil nitrogen cycling is determined by the competition between mycorrhiza and ammonia-oxidizing prokaryotes
}

\section{$\operatorname{AUTHOR}(S)$ :}

Tatsumi, Chikae; Taniguchi, Takeshi; Du, Sheng;

Yamanaka, Norikazu; Tateno, Ryunosuke

\section{CITATION:}

Tatsumi, Chikae ...[et al]. Soil nitrogen cycling is determined by the competition between mycorrhiza and ammonia-oxidizing prokaryotes. Ecology 2020, 101(3): e02963.

ISSUE DATE:

2020-03

URL:

http://hdl.handle.net/2433/245929

RIGHT:

(C) 2019 by the Ecological Society of America 


\title{
Soil nitrogen cycling is determined by the competition between mycorrhiza and ammonia-oxidizing prokaryotes
}

\author{
Chikae Tatsumi (D) ${ }^{1,5}$ Takeshi Taniguchi $(\mathbb{D}),{ }^{2}$ Sheng Du, ${ }^{3}$ Norikazu Yamanaka, ${ }^{2}$ and Ryunosuke Tateno (iD 4 \\ ${ }^{1}$ Graduate School of Agriculture, Kyoto University, Oiwake, Kitashirakawa, Sakyo, Kyoto 606-8502 Japan \\ ${ }^{2}$ Arid Land Research Center, Tottori University, 1390 Hamasaka, Tottori 680-0001 Japan \\ ${ }^{3}$ State Key Laboratory of Soil Erosion and Dryland Farming on Loess Plateau, Institute of Soil and Water Conservation, Chinese \\ Academy of Sciences, Yangling, Shaanxi 712100 China \\ ${ }^{4}$ Field Science Education and Research Center, Kyoto University, Kyoto 606-8502 Japan
}

Citation: Tatsumi, C., T. Taniguchi, S. Du, N. Yamanaka, and R. Tateno. 2020. Soil nitrogen cycling is determined by the competition between mycorrhiza and ammonia-oxidizing prokaryotes. Ecology 101(3): e02963. 10.1002/ecy.2963

\begin{abstract}
Mycorrhizal fungi have considerable effects on soil carbon (C) storage, as they control the decomposition of soil organic matter (SOM), by modifying the amount of soil nitrogen $(\mathrm{N})$ available for free-living microbes. Through their access to organic $\mathrm{N}$, ectomycorrhizal (ECM) fungi compete with free-living soil microbes; this competition is thought to slow down SOM decomposition. However, arbuscular mycorrhizal (AM) fungi cannot decompose $\mathrm{SOM}$, and therefore must wait for $\mathrm{N}$ to first be processed by free-living microbes. It is unclear what form of $\mathrm{N}$ the ECM fungi and free-living microbes compete for, or which microbial groups compete for $\mathrm{N}$ with ECM fungi. To investigate this, we focused on the $\mathrm{N}$ transformation steps (i.e., the degradation of high-molecular-weight organic matter, mineralization, and nitrification) and the microbes driving each step. Simple comparisons between AM forests and ECM forests are not sufficient to assert that mycorrhizal types would determine the $\mathrm{N}$ transformation steps in soil, because soil physiochemistry, which strongly affects $\mathrm{N}$ transformation steps, differs between the forests. We used an aridity gradient with large differences in soil moisture, $\mathrm{pH}$, and SOM quantity and quality, to distinguish the mycorrhizal and physicochemical effects on $\mathrm{N}$ transformation. Soil samples $(0-10 \mathrm{~cm}$ depth) were collected from AM-symbiotic black locust forests under three aridity levels, and from ECM-symbiotic oak forests under two aridity levels. Soil physicochemical properties, extractable $\mathrm{N}$ dynamics and abundance, composition, and function of soil microbial communities were measured. In ECM forests, the ammonia-oxidizing prokaryotic abundance was low, whereas that of ECM fungi was high, resulting in lower nitrate $\mathrm{N}$ content than in AM forests. Since ECM forests did not have lower saprotrophic fungal abundance and prokaryotic decompositional activity than the AM forests, the hypothesis that ECM fungi could reduce SOM decay and ammonification by free-living microbes, might not hold in ECM forests. However, the limitation of ECM fungi on nitrate $\mathrm{N}$ production would result in a feedback that will accelerate plant dependence on these fungi, thereby raising soil $\mathrm{C}$ storage through an increase in the ECM biomass and plant $\mathrm{C}$ investment in soils.
\end{abstract}

Key words: arbuscular mycorrhizal fungi; dryland; ectomycorrhizal fungi; nitrification; rainfall gradient; soil carbon storage.

\section{INTRODUCTION}

Mycorrhizal fungi play a critical role in soil $\mathrm{C}$ storage by controlling soil organic matter (SOM) decomposition, through their ability to utilize soil nitrogen (N; Talbot et al. 2008, Averill et al. 2014, Lindahl and Tunlid 2015, Sterkenburg et al. 2018, Zak et al. 2019). Ectomycorrhizal (ECM) fungi can produce many hydrolytic and oxidative extracellular enzymes (Chalot

Manuscript received 26 July 2019; revised 8 November 2019; accepted 26 November 2019. Corresponding Editor: Steven D. Allison.

${ }^{5}$ E-mail: tatsumi.chikae.23x@st.kyoto-u.ac.jp and Brun 1998, Courty et al. 2010, Kohler et al. 2015 but see Pellitier and Zak 2018), and obtain small organic N-bearing molecules from SOM, leaving behind a relatively C-rich substrate (Orwin et al. 2011, Averill et al. 2014). As a result, ECM fungi are thought to limit the amount of $\mathrm{N}$ available for free-living microbes, slowing down SOM decomposition by these microbial communities (Gadgil and Gadgil 1971, Averill and Hawkes 2016, Fernandez and Kennedy 2016). On the other hand, arbuscular mycorrhizal (AM) fungi lack saprotrophic ability and are believed to use inorganic rather than organic $\mathrm{N}$ (Read and Perez-Moreno 2003, Smith and Read 2008, Smith and Smith 2011, Hodge and Storer 2014). As a result, AM 
fungi do not strongly limit the amount of $\mathrm{N}$ available for free-living microbes, and therefore do not prevent SOM decomposition by these microbes.

$\mathrm{N}$ competition between ECM fungi and free-living microbes is supported by models and observed global patterns of soil C storage (Orwin et al. 2011, Averill et al. 2014). Nonetheless, ECM fungi do not always appear to inhibit SOM decomposition (Drake et al. 2011, Phillips et al. 2014, Brzostek et al. 2015), and direct tests for $\mathrm{N}$ competition are still lacking (Averill and Hawkes 2016, Fernandez and Kennedy 2016). In particular, it is unknown which form of $\mathrm{N}$ is competed for and which microbial groups compete for the $\mathrm{N}$ with ECM fungi. The process of $\mathrm{N}$ transformation comprises three main steps: (1) degradation of high-molecular-weight organic matter, (2) mineralization, and (3) nitrification. Each step is primarily driven by different microbes. Fungi and prokaryotes are, respectively, the main drivers of degradation and mineralization (Moore et al. 2003). Ammoniaoxidizing bacteria and archaea play an important role in the rate-limiting process of nitrification (Kowalchuk and Stephen 2001, Isobe et al. 2015). Microbial taxa vary in their ability to transform N, with some taxa highly accelerating each $\mathrm{N}$ transformation step. For example, the decompositional ability of prokaryotic taxa, and especially their ability to produce decomposition enzymes, varies among taxa (Fierer et al. 2007, Zimmerman et al. 2013). Ammonia-oxidizing bacteria and archaea also have different oxidization capabilities; ammonia-oxidizing bacteria are more competitive at high ammonium concentrations than ammonia-oxidizing archaea (Di et al. 2009, Chen et al. 2013, Banning et al. 2015). A lower abundance of microbial drivers and their $\mathrm{N}$-derived products in one of the $\mathrm{N}$ transformation steps in the ECM forests would provide strong evidence for $\mathrm{N}$ competition during the $\mathrm{N}$ transformation step (as opposed to the AM forests). For example, $\mathrm{N}$ competition is likely to occur during mineralization if the prokaryotic decompositional ability and ammonium $\mathrm{N}$ pool are lower in the ECM forests than in the AM forests.

Simple comparisons of the $\mathrm{N}$ transformation steps and microbial communities between the ECM and AM forests, cannot clarify the existence of mycorrhizal-mediated $\mathrm{N}$ competition, since many environmental factors, along with mycorrhizal abundance, simultaneously differ between the two forest types. Several studies have reported a negative correlation between the forest's ECM to AM tree ratio and soil $\mathrm{pH}$; this has been attributed to litter quality (Phillips et al. 2013, Cheeke et al. 2016, Midgley and Phillips 2016). The ratio can be positively correlated with soil moisture, because ECM-dominated forests have a thicker litter layer that prevents evaporation, due to the poor chemical quality of the litter from ECM trees (Cornelissen et al. 2001, Phillips et al. 2013). These co-changing physicochemical properties are highly important factors for soil microbes, and thus for soil $\mathrm{N}$ cycling, as low soil $\mathrm{pH}$ limits the proliferation of soil ammonia-oxidizers and therefore limits the nitrification rate (Nicol et al. 2008, Stempfhuber et al. 2015), while high soil moisture reduces ammonium $\mathrm{N}$ content by enhancing the $\mathrm{N}$ uptake of plants (Reichmann et al. 2013, Homyak et al. 2017). Therefore, it could be that the soil physicochemical properties are the reasons behind the decline in soil inorganic $\mathrm{N}$ content observed at increasing ratios of ECM trees to AM trees (Phillips et al. 2013, Cheeke et al. 2016, Midgley and Phillips 2016).

To understand mycorrhizal effects separately from the effects of soil moisture and $\mathrm{pH}$, we propose to use an aridity gradient in dryland forests. Dryland soils impose many environmental stresses, including low soil moisture and high $\mathrm{pH}$ (alkalinity), which increase along the aridity gradient (Jiao et al. 2016, Tatsumi et al. 2019). The aridity gradient can also be used to differentiate between the effects of SOM quality and quantity and type of mycorrhiza; regardless of the mycorrhizal effects, the aridity gradient will cause variation in SOM, partly as a result of its effects on tree biomass (Feral et al. 2003, Tatsumi et al. 2019). In addition, SOM quality and quantity of the deeper soil layers should be different from the SOM quality and quantity in the surface soils, although the difference in moisture and $\mathrm{pH}$ between subsurface and surface soils is generally relatively minor (Fierer et al. 2003, Thoms et al. 2010).

Here, to evaluate $\mathrm{N}$ competition between ECM fungi and free-living microbes, we studied the effects of mycorrhiza and soil physicochemical properties along environmental gradients (particularly a dryland aridity gradient) on soil $\mathrm{N}$ transformation steps and its microbial drivers. We examined AM-symbiotic black locust (Robinia pseudoacacia) (Yang et al. 2014) and ECMsymbiotic oak (Quercus liaotungensis) forests (Zhang et al. 2013) on the Loess Plateau in northeastern China. To study $\mathrm{N}$ transformation steps, we focused on the abundance of microbial drivers for each transformation step (saprotrophic and ECM fungi for degradation, Ndegrading prokaryotes for mineralization, and ammonia-oxidizing prokaryotes for nitrification) and their content of $\mathrm{N}$ products (extractable organic $\mathrm{N}$ (EON), ammonium $\mathrm{N}$, and nitrate $\mathrm{N}$, respectively). We calculated microbial abundance and extractable $\mathrm{N}$ content per gram of soil and per unit of $\mathrm{N}$ stock to consider the effects of resource abundance on each step. We expected one step in the $\mathrm{N}$ transformation steps, regardless of the aridity gradient, to be clearly limited in the ECM forests. That is, both microbial driver abundance and its $\mathrm{N}$ product content of an $\mathrm{N}$ transformation step (degradation, mineralization or nitrification) will be consistently lower in the ECM forest, compared with the AM forests.

\section{Materials And Methods}

\section{Study site}

This study was conducted in three AM-symbiotic black locust forests and three ECM-symbiotic oak 
forests from the southern to central part of the Loess Plateau of China. Black locust forests were largely planted in the 1960s and oak forests are the native cli$\max$ forests here. These forests are very common in this region ( $\mathrm{Du}$ et al. 2011). The three black locust forests were located in a mountainous area near Yongshou County (Yongshou, 3448 $\mathrm{N}, 107^{\circ} 59^{\prime} \mathrm{E}$ ), near Yan'an City (Mt. Gonglushan, 36 $25^{\prime} \mathrm{N}, 109^{\circ} 32^{\prime} \mathrm{E}$ ), and near Ansai County (Zhifanggou, $36^{\circ} 45^{\prime} \mathrm{N}, 109^{\circ} 15^{\prime} \mathrm{E}$ ) in Shaanxi Province, China. These were called BL-Wet site, BL-Med site, and BL-Dry site, respectively (Tatsumi et al. 2019). Three oak forests were located in a mountainous area near Fuxian County (eastern Fuxian, $36^{\circ} 05^{\prime} \mathrm{N}, 109^{\circ} 33^{\prime} \mathrm{E}$, and western Fuxian, N36 $04^{\prime} \mathrm{N}$, $109^{\circ} 09^{\prime}$ E) and Mt. Gonglushan in Shaanxi Province. Because these two sites in Fuxian had almost the same mean annual rainfall, we defined these two sites as OakWet site. We called Mt. Gonglushan the Oak-Med site. It was difficult to find an Oak-Dry site, because this region was categorized as a forest-steppe transitional zone, i.e., the drought boundary of the forest, and because most of the natural oak forests were already cut down by human activity (Lü et al. 2003). Mean annual rainfall gradually decreased from the southeast to northwest (Yamanaka et al. 2014), and reference evaporation increased from south to north in our research region $(\mathrm{Li}$ et al. 2012). Mean annual rainfall and mean annual air temperature were $606 \mathrm{~mm}$ and $10.8^{\circ} \mathrm{C}$ in the BL-Wet site (Li et al. 2015), $577 \mathrm{~mm}$ and $9.0^{\circ} \mathrm{C}$ in the Oak-Wet site (Li and Shao 2006), $514 \mathrm{~mm}$ and $10.2^{\circ} \mathrm{C}$ in the BL-Med and Oak-Med site (Otsuki et al. 2005), and $449 \mathrm{~mm}$ and $8.8^{\circ} \mathrm{C}$ in the BL-Dry site (Qiu et al. 2012).

In each forest, we established four plots $(20 \times 20 \mathrm{~m})$ at a distance of $>30 \mathrm{~m}$ from each other. All the plots were located on a flat or gentle slope near a ridge. The forest canopy was closed, and more than $90 \%$ of the canopy of all these plots were occupied by dominant species, black locust or oak. All forests had understory cover, consisting of shrubs and herbaceous species. There were no representative ectomycorrhizal trees (i.e., Pinaceae, Salicaceae, Myrtaceae, Fagaceae, and Betulaceae) in the black locust forests (Wang and Qiu 2006). Tree density, mean tree size (DBH and height), and the amount of organic layer in each site is shown in Appendix S1: Table S1.

\section{Soil sampling and measurement of soil physicochemical properties}

Soil samples $(0-10 \mathrm{~cm}$ in depth) were taken from four points in each plot. The sampling points were approximately $10 \mathrm{~m}$ from each other. The four soil samples were composited and mixed into one sample and divided into subsamples for analysis of physicochemical properties, extractable N, and DNA. Samplings were conducted during the following periods: (1) for the BL-Wet and BL-Dry sites, September 2015, April, June, and September 2016, August 2017, and June and October 2018; (2) for the BL-Med and Oak-Med sites, September 2015, April, June, and September 2016, June, August, and October 2017, and June and October 2018; and (3) for the Oak-Wet site, October 2017 and June and October 2018. To separate the effects of SOM quantity and quality from other environmental factors (like soil $\mathrm{pH}$ ), subsurface soil samples $(20-30 \mathrm{~cm}$ in depth) were taken at the same places as the $0-10 \mathrm{~cm}$ soil samples, in October 2018. Part of the soil data on the black locust forests is presented in Tatsumi et al. (2019).

Soil water content was measured by drying the soil at $105^{\circ} \mathrm{C}$ for more than $3 \mathrm{~d}$. Soil $\mathrm{pH}$ was measured using a pH meter (D-51; HORIBA, Kyoto, Japan) with a 2:5 soil/water suspension. After grinding the soil samples, the total $\mathrm{C}$ content was measured using the dichromate oxidation method and the total $\mathrm{N}$ content was measured using the Kjeldahl method. After collection and incubation at $\sim 25^{\circ} \mathrm{C}$ (for more than $6 \mathrm{~d}$ ), soil dissolved $\mathrm{C}$ and $\mathrm{N}$ were extracted with $2 \mathrm{~mol} / \mathrm{L} \mathrm{KCl}$ at a $1: 10$ soil/extractant ratio. The amounts of total extractable organic $\mathrm{C}$ (EOC) and total extractable $\mathrm{N}$ in the extracts were measured using TOC-LCPH/CPN + TNM-L (SHIMADZU, Kyoto, Japan) by the $680^{\circ} \mathrm{C}$ combustion catalytic oxidation method (using acidification and sparging) and by the $720^{\circ} \mathrm{C}$ catalytic thermal decomposition/chemiluminescence methods, respectively. The amounts of ammonium and nitrate $\mathrm{N}$ in the extracts were measured using a Bran + Luebbe AutoAnalyzer III (BLTEC, Tokyo, Japan) with the colorimetric method. The amount of soil KCl-extractable organic N (EON) was calculated based on the differences between total extractable $\mathrm{N}$ and inorganic $\mathrm{N}$, which was the sum of ammonium and nitrate $\mathrm{N}$. Soil net $\mathrm{N}$ mineralization and nitrification rates were calculated based on the differences in inorganic $\mathrm{N}$ and nitrate $\mathrm{N}$, respectively, before and after incubation. These transformation rates were measured by laboratory incubation released from alive plants. The extractable $\mathrm{N}$ content and the transformation rate were calculated as units per gram of soil and as units per milligram $\mathrm{N}$.

\section{Soil DNA extraction, quantification by real-time quantitative $P C R$, and sequencing analysis}

DNA was extracted from 0.25 -g soil samples using the MoBio Powersoil DNA Isolation Kit (MoBio, Carlsbad, California, USA). The extracts were stored in a freezer until further analysis. Real-time quantitative polymerase chain reaction (qPCR) was performed using the Light Cycler Nano thermal cycler (Roche Diagnostics K.K., Mannheim, Germany), with SYBR Green I as the intercalating dye. Fungal ITS and bacterial and archaeal 16S rRNA were targeted to estimate the population size of each soil microbial group. The abundance of ammoniaoxidizing bacteria and archaea were also estimated by bacterial and archaeal amo $A$ genes. The subsequent step in the analysis has been described in detail by Tatsumi et al. (2019) and Iwaoka et al. (2018). 
For sequencing analysis, amplification of ITS and 16S rRNA genes in DNA extracts was performed using the primer sets ITS1F_KYO2/ITS2_KYO2 (Toju et al. 2012) and U519f (Suzuki and Giovannoni 1996)/U785r (Wang and Qian 2009), respectively. Sequencing was performed on an Ion Personal Genome Machine (PGM; Thermo Fisher Scientific, Waltham, Massachusetts, USA). The subsequent step for $16 \mathrm{~S}$ rRNA analysis has been described in detail by Iwaoka et al. (2018). ITS sequences shorter than 360 base pairs (bp) in length were removed; ITSx was used to extract fungal ITS sequences (Bengtsson-palme et al. 2013). The remaining steps were the same as for $16 \mathrm{~S}$ rRNA sequences. Sequence data were deposited in the Sequence Read Archive at NCBI under accession numbers DRA008376 and DRA008550.

To analyze the fungal and prokaryotic community structure, the read numbers were equalized to 5,645 and 2,100 reads, respectively, using random pick up based on the minimum read number. To search fungal trophic mode from fungal taxonomy and to predict functional gene abundance based on 16S rRNA gene, FUNGuild database (Nguyen et al. 2016) and PICRUSt pipeline (Langille et al. 2013) were used, respectively. FUNGuild assigns fungal phylotypes to trophic modes (e.g., saprotroph, symbiotroph, pathotroph). We picked the ECM guild from symbiotrophs. The FUNGuild program often assigns multiple trophic modes and guilds for single OTUs (e.g., saprotrophsymbiotroph), and such OTUs were counted in both groups, i.e., OTUs of saprotroph-symbiotroph were counted both as saprotroph and as symbiotroph. To perform PICRUSt, sequences were repicked at a 97\% similarity threshold, with reference to the Greengenes database (version 13_05) and OTUs were named using the Greengenes IDs. The OTU table was equalized to 1,000 reads and normalized by gene copy number. Functional metagenome profiles were predicted with PICRUSt (version 1.1.1), generating a table of Kyoto Encyclopedia of Gene and Genomes (KEGG) Orthologs (KOs; Kanehisa and Goto 2000). We selected the genes necessary for coding enzymes commonly measured to evaluate soil $\mathrm{N}$ cycling (Saiya-Cork et al. 2002, Sinsabaugh et al. 2008, Isobe et al. 2018), i.e., $\beta 1,4-N$-acetylglucosaminidase (NAG; EC 3.2.1.52), chitinase (EC 3.2.1.14), leucine aminopeptidase (LAP; EC 3.4.11.1), arginase (EC 3.5.3.1), and urease (EC 3.5.1.5). The saprotrophic and ECM fungal gene abundances were calculated by multiplying their FUNGuild-based relative abundance and the qPCR-based fungal ITS gene abundance. The prokaryotic $\mathrm{N}$ cycling gene abundance was calculated by multiplying their PICRUSt-based relative abundance and the qPCRbased prokaryotic 16S rRNA gene abundance. Ammonia-oxidizing prokaryote abundances were directly estimated by qPCR as previously described. The gene abundances were calculated as units per gram soil and units per milligram $\mathrm{N}$.

\section{Statistical analyses}

We set the level of significance at 5\% for all tests. A linear mixed-effect model (LMM) for forest type (black locust forests $=-1$, oak forests $=1$ ) and aridity was used to test the effects of forest type and the aridity gradient on soil parameters. We used the standardized minus mean annual rainfall to indicate the aridity level. The data set from all the surface soil samples $(0-10 \mathrm{~cm})$ collected in several occasions was used for the LMM for forest type and aridity. Plots (the Oak-Wet site had eight plots and the other sites had four plots) and sampling occasions were introduced as random variables in these models. LMM for forest type, aridity, and depth was also used to test the effects of forest type, the aridity gradient, and the soil depth $(0-10 \mathrm{~cm}$ depth $=-1,20$ $30 \mathrm{~cm}$ depth $=1$ ) on soil parameters. The data set from the soil samples collected in October 2018 was used for the LMM for forest type, aridity, and depth. The sampling plot was introduced as a random variable in these models. The objective variables were standardized in the LMM, using means and SDs. The lme4 and lmerTest packages (Bates et al. 2014, Kuznetsova et al. 2017) in R (version 3.1.2; R Core Team 2014) were used for the linear mixed-effect models.

We conducted path analysis to identify how soil $\mathrm{N}$ transformation steps were determined by forest type and aridity (minus mean annual rainfall). Here, we used the data set from all surface soil samples $(0-10 \mathrm{~cm})$ collected on several occasions. We also conducted path analysis to identify how soil $\mathrm{N}$ transformation steps are determined by forest type, aridity, and soil depth. For this, we used the October 2018 data set. We expected that forest type, aridity, and soil depth would affect soil water content, $\mathrm{pH}$, total $\mathrm{N}$ content, the $\mathrm{C}: \mathrm{N}$ ratio, and relative abundance of ectomycorrhizal fungi, and these factors would in turn affect EON, ammonium $\mathrm{N}$, and nitrate $\mathrm{N}$ content. We used only the standardized values. For the path analysis, we used the structural equation modeling (sem) package of $\mathrm{R}$ (Byrnes et al. 2016) and path diagrams were illustrated after nonsignificant relationships were eliminated. Permutational multivariate analyses of variance (PerMANOVA) were used to test the significance of the effects of forest type and aridity (and soil depth) on the community via the adonis function of the $\mathrm{R}$ vegan package (Oksanen et al. 2016).

\section{Results}

\section{Soil physicochemical properties}

Both soil water content and $\mathrm{pH}$ were significantly affected by the aridity gradient (Table 1). Soil total C and $\mathrm{N}$ content and the $\mathrm{C}: \mathrm{N}$ ratio were significantly affected by the interaction, as well as by forest type. Water content decreased and $\mathrm{pH}$ increased with the aridity gradient. Total $\mathrm{C}$ and $\mathrm{N}$ content and the $\mathrm{C}: \mathrm{N}$ ratio were higher in the oak forests. 
TABLE 1. Soil water content, $\mathrm{pH}$, total carbon $(\mathrm{C})$, and nitrogen $(\mathrm{N})$ contents, $\mathrm{C}: \mathrm{N}$ ratio, EOC content, and EOC: EON ratio of surface soils $(0-10 \mathrm{~cm})$.

\begin{tabular}{|c|c|c|c|c|c|c|c|c|}
\hline \multirow[b]{2}{*}{ Parameter } & \multicolumn{3}{|c|}{ Black locust forest } & \multicolumn{2}{|c|}{ Oak forest } & \multirow[b]{2}{*}{ Type } & \multirow[b]{2}{*}{ Aridity } & \multirow{2}{*}{$\begin{array}{l}\text { Type } \times \\
\text { Aridity }\end{array}$} \\
\hline & Wet site & Med site & Dry site & Wet site & Med site & & & \\
\hline Water content $(\%)$ & $21.7 \pm 4.5$ & $11.5 \pm 4.4$ & $10.0 \pm 3.0$ & $19.8 \pm 4.8$ & $15.0 \pm 5.4$ & 0.03 & $-0.74 * * *$ & 0.12 \\
\hline $\mathrm{pH}$ & $7.07 \pm 0.66$ & $7.92 \pm 0.33$ & $8.20 \pm 0.22$ & $7.63 \pm 0.22$ & $7.55 \pm 0.36$ & -0.05 & $0.54^{*}$ & -0.42 \\
\hline C content $(\mathrm{g} / \mathrm{kg})$ & $30.3 \pm 7.5$ & $25.3 \pm 5.0$ & $12.9 \pm 5.4$ & $40.2 \pm 10.1$ & $41.0 \pm 8.1$ & $0.66^{* * *}$ & -0.25 & $0.34 *$ \\
\hline $\mathrm{N}$ content $(\mathrm{g} / \mathrm{kg})$ & $2.79 \pm 0.58$ & $2.31 \pm 0.43$ & $1.16 \pm 0.45$ & $3.01 \pm 0.66$ & $3.23 \pm 0.57$ & $0.52 * * *$ & -0.27 & $0.51 * *$ \\
\hline $\mathrm{C}: \mathrm{N}$ ratio & $10.7 \pm 0.7$ & $10.9 \pm 0.4$ & $11.0 \pm 0.8$ & $13.3 \pm 0.9$ & $12.6 \pm 0.7$ & $0.81 * * *$ & -0.20 & $-0.28^{*}$ \\
\hline EOC content $(\mathrm{mg} / \mathrm{kg})$ & $233 \pm 268$ & $241 \pm 42$ & $180 \pm 28$ & $488 \pm 165$ & $452 \pm 159$ & $0.62 * * *$ & -0.19 & -0.08 \\
\hline EOC : EON ratio & $12.0 \pm 6.6$ & $15.8 \pm 6.3$ & $33.6 \pm 44.7$ & $11.3 \pm 4.7$ & $12.5 \pm 4.0$ & $-0.16^{*}$ & $0.32 *$ & -0.11 \\
\hline
\end{tabular}

Notes: Values represent mean $\pm \mathrm{SD}$. Right side shows standardized coefficients and $P$ values $(* P<0.05, * * P<0.01$, $* * * P<0.001$ ) based on linear mixed-effect model for forest type (black locust forests $=-1$, oak forests $=1$, Type), standardized minus mean annual rainfall (Aridity), and their interactions (Type $\times$ Aridity). The models were performed with sampling occasion and plotted as random variables. Significant values are bolded. EOC, extractable organic C; EON, extractable organic N.

\section{Soil extractable $N$ dynamics}

Soil extractable $\mathrm{N}$ composition was highly changed by the forest type (Fig. 1). EON content was significantly higher in the oak forests, and nitrate $\mathrm{N}$ content was significantly higher in the black locust forests. EON content was also affected by the aridity gradient; it declined along the gradient. Ammonium $\mathrm{N}$ content was not significantly affected by the forest type, aridity gradient, or their interaction. Net $\mathrm{N}$ mineralization and net nitrification rate were not affected by forest type or the aridity gradient, but were significantly affected by their interaction (Appendix S1: Fig. S1). The path analysis showed that aridity affected soil EON, ammonium $\mathrm{N}$, and nitrate $\mathrm{N}$ content through modifying soil moisture, $\mathrm{pH}$, and total $\mathrm{N}$ content (Fig. 2). Soil EON, ammonium N, and nitrate $\mathrm{N}$ contents were also affected by the forest type, through the modification of the total $\mathrm{N}$ content,

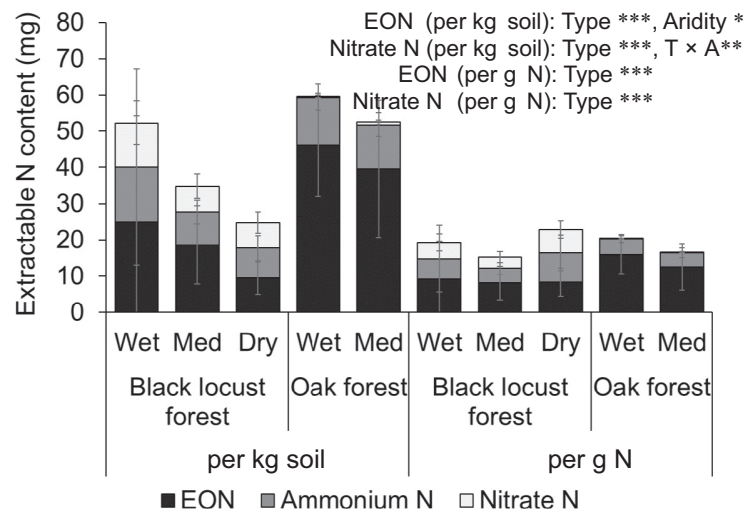

FIG. 1. Soil extractable organic N (EON), ammonium N, and nitrate $\mathrm{N}$ content (mean $\pm \mathrm{SD}$ ) of surface soils $(0-10 \mathrm{~cm})$. The extractable $\mathrm{N}$ contents were shown per kilogram soil and per gram N. The significant results of the linear mixed-effect model for forest type (Type), standardized minus mean annual rainfall (Aridity) and their interactions $(\mathrm{T} \times \mathrm{A})$ are shown in the upper right. The models were performed with sampling occasion and plot as random variables. ${ }^{*} P<0.05 ; * * P<0.01$; $* * * P<0.001$ the C:N ratio, and the ECM relative abundance. The strongest effect on soil EON content and especially on nitrate $\mathrm{N}$ content was applied by the relative abundance of ECM. Oak forests had higher EON and lower nitrate $\mathrm{N}$ content than black locust forests, even when the total $\mathrm{N}$ resource of the soil was taken into account (Fig. 1).

\section{Soil fungal community}

Fungal ITS gene abundance based on qPCR analysis was significantly affected by the forest type, aridity gradient, and their interaction (Table 2). The fungal abundance was higher in the oak forests, and the abundance decreased along the aridity gradient (Table 2). Fungal community structure was significantly affected by forest type (PerMANOVA, $F_{1,1}=35.3, R^{2}=0.17, P<0.001$ ), the aridity (PerMANOVA, $F_{1,1}=16.9, R^{2}=0.08$, $P<0.001$ ), and their interaction (PerMANOVA, $F_{1,1}$ $\left.=6.6, R^{2}=0.03, P<0.001\right)$. NMDS separated samples depending on forest type and the aridity gradient (Appendix S1: Fig. S2a).

The abundances of saprotrophs and ECM were significantly affected by forest type, and they were higher in the oak forests (Fig. 3). The abundance of ECM was also significantly affected by the aridity gradient, and the abundances of saprotrophs and ECM were significantly affected by the interaction between forest type and aridity gradient. When considering the unit $\mathrm{N}$ resources, the saprotrophic fungal abundance was significantly affected only by the interaction, while the ECM fungal abundance was significantly affected by the forest type, the aridity, and the interaction. ECM fungal abundance per unit $\mathrm{N}$ was also higher in the ECM forest, and decreased along the aridity gradient. The dominant ECM taxa were the Sebacinaceae, Thelephoraceae, and Cortinarius.

\section{Soil prokaryotic community}

Based on the qPCR analysis, total bacterial abundance was affected only by the aridity gradient (and not 


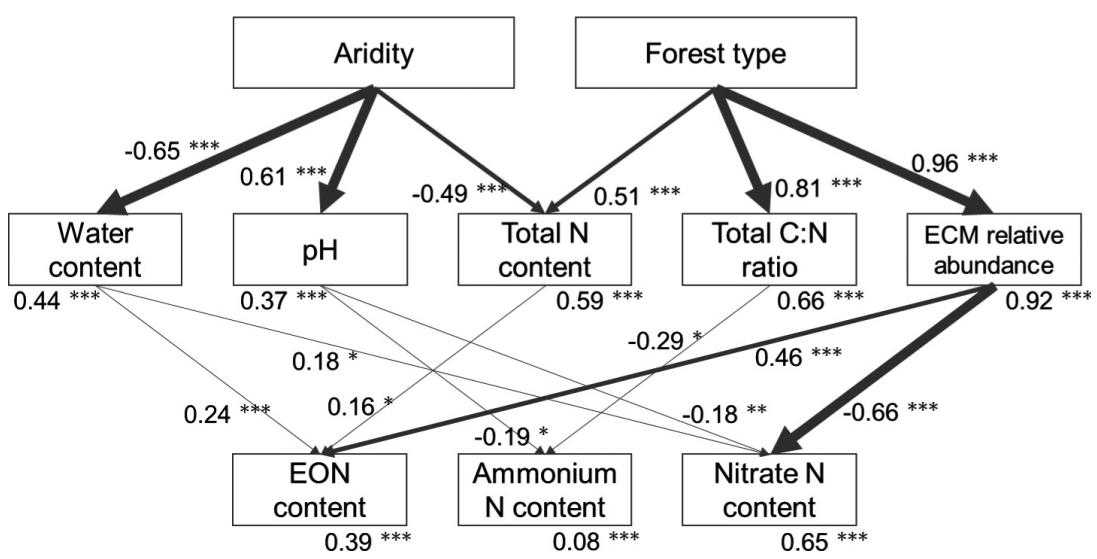

FIG. 2. The path diagram of the relationships among the parameters of the experimental design: forest type and aridity (minus mean annual rainfall), the mediating variables (water content, $\mathrm{pH}$, total $\mathrm{N}$ content, total $\mathrm{C}: \mathrm{N}$ ratio, and ECM relative abundance), and extractable $\mathrm{N}$ contents of surface soils $(0-10 \mathrm{~cm})$. Standardized values were used. Values and asterisks next to arrows indicate path coefficients and $P$ values $\left(* P<0.05\right.$; $\left.{ }^{*} P<0.01 ; * * * P<0.001\right)$, respectively. Value under the box represents coefficient of determination. The significant relationships are illustrated. Forest type was read as ordinal categorical data: black locust forests $=-1$; oak forests $=1$.

TABLE 2. $\log _{10}$-transformed abundance of fungal ITS gene, bacterial, and archaeal 16S rRNA gene abundance based on qPCR, and $\log _{10}$-transformed predicted abundances of prokaryotic genes associated with decomposition of surface soils $(0-10 \mathrm{~cm})$.

\begin{tabular}{|c|c|c|c|c|c|c|c|c|}
\hline \multirow[b]{2}{*}{ Source } & \multicolumn{3}{|c|}{ Black locust forest } & \multicolumn{2}{|c|}{ Oak forest } & \multirow[b]{2}{*}{ Type } & \multirow[b]{2}{*}{ Aridity } & \multirow[b]{2}{*}{ Type $\times$ Aridity } \\
\hline & Wet site & Med site & Dry site & Wet site & Med site & & & \\
\hline \multicolumn{9}{|l|}{ per g soil } \\
\hline Fungi & $7.69 \pm 0.48$ & $7.46 \pm 0.44$ & $7.57 \pm 0.50$ & $8.37 \pm 0.53$ & $7.80 \pm 0.60$ & $0.33 * * *$ & $-0.49 * * *$ & $-0.46^{* * *}$ \\
\hline Bacteria & $9.15 \pm 0.49$ & $9.06 \pm 0.49$ & $8.99 \pm 0.60$ & $9.38 \pm 0.45$ & $9.05 \pm 0.56$ & 0.02 & $-0.19^{*}$ & -0.12 \\
\hline Archaea & $6.85 \pm 0.42$ & $6.85 \pm 0.39$ & $6.81 \pm 0.37$ & $6.71 \pm 0.33$ & $6.42 \pm 0.54$ & $-0.44 * * *$ & 0.07 & 0.18 \\
\hline NAG & $9.03 \pm 0.50$ & $8.40 \pm 0.50$ & $8.81 \pm 0.49$ & $8.51 \pm 0.49$ & $8.79 \pm 0.49$ & 0.07 & $-0.26^{*}$ & -0.15 \\
\hline Chitinase & $8.88 \pm 0.49$ & $8.34 \pm 0.49$ & $8.73 \pm 0.50$ & $8.40 \pm 0.49$ & $8.70 \pm 0.50$ & 0.06 & $-0.22 *$ & -0.12 \\
\hline LAP & $8.83 \pm 0.59$ & $8.24 \pm 0.57$ & $8.68 \pm 0.60$ & $8.31 \pm 0.58$ & $8.63 \pm 0.59$ & $0.11^{*}$ & $-0.20^{*}$ & $-0.17^{*}$ \\
\hline Arginase & $9.25 \pm 0.47$ & $8.64 \pm 0.46$ & $9.12 \pm 0.45$ & $8.80 \pm 0.44$ & $9.10 \pm 0.43$ & $0.12 *$ & $-0.25^{* *}$ & -0.14 \\
\hline Urease & $8.93 \pm 0.57$ & $8.35 \pm 0.56$ & $8.78 \pm 0.57$ & $8.48 \pm 0.57$ & $8.75 \pm 0.57$ & $0.11 * *$ & $-0.23^{* *}$ & $-0.15^{*}$ \\
\hline \multicolumn{9}{|l|}{ per mg N } \\
\hline Fungi & $7.25 \pm 0.47$ & $7.11 \pm 0.44$ & $7.54 \pm 0.49$ & $7.90 \pm 0.58$ & $7.30 \pm 0.62$ & $0.24 * * *$ & $-0.35^{* * *}$ & $-0.49 * * *$ \\
\hline Bacteria & $8.71 \pm 0.45$ & $8.70 \pm 0.48$ & $8.95 \pm 0.57$ & $8.91 \pm 0.51$ & $8.54 \pm 0.57$ & -0.14 & 0.10 & -0.23 \\
\hline Archaea & $6.41 \pm 0.39$ & $6.49 \pm 0.39$ & $6.78 \pm 0.37$ & $6.24 \pm 0.41$ & $5.91 \pm 0.55$ & $-0.47 * * *$ & 0.32 & -0.14 \\
\hline NAG & $8.59 \pm 0.46$ & $7.96 \pm 0.47$ & $8.37 \pm 0.46$ & $8.07 \pm 0.46$ & $8.35 \pm 0.45$ & -0.10 & 0.03 & -0.26 \\
\hline Chitinase & $8.53 \pm 0.48$ & $7.98 \pm 0.48$ & $8.38 \pm 0.49$ & $8.04 \pm 0.49$ & $8.35 \pm 0.49$ & -0.11 & 0.06 & $-0.25^{*}$ \\
\hline LAP & $8.80 \pm 0.57$ & $8.20 \pm 0.55$ & $8.64 \pm 0.58$ & $8.27 \pm 0.56$ & $8.59 \pm 0.56$ & -0.08 & 0.07 & $-0.26^{*}$ \\
\hline Arginase & $8.78 \pm 0.53$ & $8.17 \pm 0.52$ & $8.65 \pm 0.50$ & $8.33 \pm 0.49$ & $8.63 \pm 0.48$ & -0.05 & 0.02 & $-0.25^{*}$ \\
\hline Urease & $8.42 \pm 0.58$ & $7.85 \pm 0.57$ & $8.28 \pm 0.58$ & $7.97 \pm 0.58$ & $8.24 \pm 0.58$ & -0.07 & 0.06 & $-0.25^{*}$ \\
\hline
\end{tabular}

Notes: Values represent mean $\pm \mathrm{SD}$. The predicted abundances of prokaryotic genes were calculated by multiplying the qPCRbased prokaryotic 16S rRNA gene abundance and the PICRUSt-based relative abundances of genes per 1,000 reads. The gene abundances were shown per gram soil and per milligram N. Right side shows standardized coefficients and $P$ values $\left({ }^{*} P<0.05\right.$; ${ }^{* *} P<0.01 ;{ }^{* * *} P<0.001$ ) based on linear mixed-effect model for forest type (black locust forests $=-1$, oak forests $=1$, Type), standardized minus mean annual rainfall (Aridity) and their interactions (Type $\times$ Aridity). The models were performed with sampling occasion as a random variable. Significant values are bolded. NAG, $\beta 1,4-N$-acetylglucosaminidase; LAP, leucine aminopeptidase.

the forest type; Table 2). Total archaeal abundance, however, was significantly higher in black locust forests, with most of the archaea being ammonia-oxidizers (Table 2, Fig. 4). The prokaryotic community structure was determined by the forest type (PerMANOVA, $F_{1,1}=25.3$, $R^{2}=0.13, P<0.001$ ), the aridity (PerMANOVA, $F_{1,1}$ $\left.=18.2, R^{2}=0.09, \quad P<0.001\right)$, and their interaction
(PerMANOVA, $\quad F_{1,1}=3.9, \quad R^{2}=0.02, \quad P<0.001$ ) . NMDS separated samples based on the forest type and the aridity gradient (Appendix S1: Fig. S2b). Predicted abundances of LAP, arginase, and urease were significantly affected by the forest type, and higher in the oak forests (Table 2). Those of all the N-degrading genes were significantly affected by the aridity and those of 


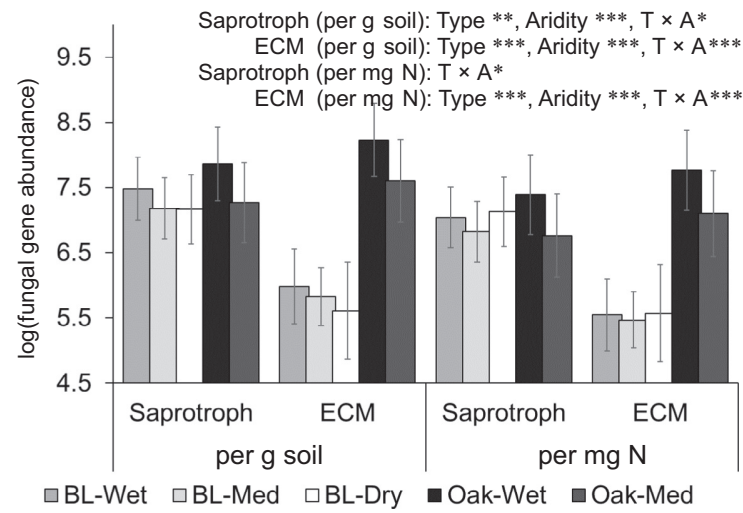

FIG. 3. Relative abundance of saprotrophic and ectomycorrhizal (ECM) fungal trophic groups (mean \pm SD) of surface soils $(0-10 \mathrm{~cm})$, based on trophic mode (saprotroph) and guild (ECM) of FUNGuild. The abundances were calculated by multiplying the qPCR-based fungal ITS gene abundance and the FUNGuild-based relative abundances. The gene abundances were shown per gram soil and per milligram N. BL, black locust. The significant results of the linear mixed-effect model for forest type (Type), standardized minus mean annual rainfall (Aridity), and their interactions $(\mathrm{T} \times \mathrm{A})$ are shown in the upper right. The models were performed with sampling occasion and plot as random variables. ${ }^{*} P<0.05$; ${ }^{* *} P<0.01$; $* * * P<0.001$

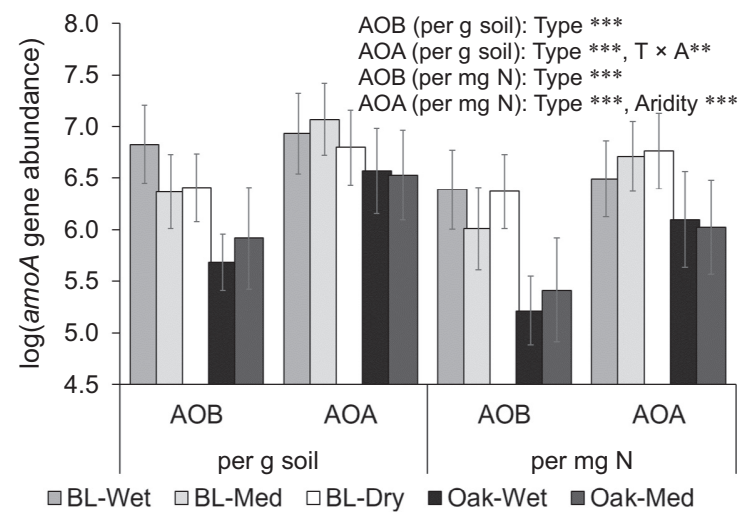

FIG. 4. Abundance of soil ammonia-oxidizing bacterial (AOB) and archaeal (AOA) amo $A$ gene abundance (mean $\pm \mathrm{SD})$ of surface soils $(0-10 \mathrm{~cm})$. The gene abundances were shown per gram soil and per milligram $\mathrm{N}$. The significant results of linear mixed-effect model for forest type (Type), standardized minus mean annual rainfall (Aridity), and their interactions $(\mathrm{T} \times \mathrm{A})$ are shown in the upper right. The models were performed with sampling occasion and plot as random variables. $* P<0.05 ; * * P<0.01 ; * * * P<0.001$.

LAP and urease were significantly affected by the interaction. When considering the unit $\mathrm{N}$ resources, those of $\mathrm{N}$-degrading genes were not significantly affected by the forest type or the aridity, but by the interaction only (Table 2).

Soil ammonia-oxidizing bacterial and archaeal abundances based on qPCR analysis were significantly affected by the forest type and their abundance was higher in the oak forests (Fig. 4). The ammonia-oxidizing archaeal abundance was also affected by the interaction. Even when we considered the $\mathrm{N}$ resource unit, the ammonia-oxidizing bacterial and archaeal abundances were still significantly affected by the forest type, and were higher in the black locust forest (Fig. 4). The ammonia-oxidizing archaeal abundance per unit $\mathrm{N}$ was also significantly affected by the aridity, and it increased along the aridity gradient.

\section{Soil $N$ transformation steps and microbial communities in subsurface soils}

Total $\mathrm{C}$ and $\mathrm{N}$ contents and the $\mathrm{C}: \mathrm{N}$ ratios differed significantly depending on the soil depth, as the $\mathrm{C}$ and $\mathrm{N}$ contents and ratio were largely lower in subsurface soils at the same sampling occasion (Appendix S1: Table S2). The quantity and quality of SOM vary more than did other factors, like moisture and $\mathrm{pH}$, (Appendix S1: Table S2); this result was expected and has also been observed in other studies (Fierer et al. 2003, Thoms et al. 2010). All the extractable N content was also significantly affected by soil depth, as the contents were lower in the subsurface soils (Appendix S1: Fig. S3). Nitrate $\mathrm{N}$ content was still higher in the black locust forests and its content was almost 0 in the oak forests, even in the subsurface soils. The path analysis for samples from October 2018, wherein soil depth was an added factor affecting soil physicochemical properties, as well as the aridity and forest type, showed that the soil $\mathrm{C}: \mathrm{N}$ ratio strongly affected EON content and ammonium $\mathrm{N}$ content, but ECM relative abundance, which was not affected by soil depth, was still strongly affected nitrate $\mathrm{N}$ content (Appendix S1: Fig. S4). PerMANOVA showed the fungal community being more strongly affected by forest type (PerMANOVA, $\left.F_{?, \text { ? }}=9.0, R^{2}=0.15, P<0.001\right)$ than by aridity (PerMANOVA, $\left.F_{?, ?}=3.6, R^{2}=0.06, P<0.001\right)$, or by soil depth (PerMANOVA, $F_{?, ?}=3.5, R^{2}=0.06, P<0.001$ ), but the prokaryotic community was more strongly affected by soil depth (PerMANOVA, $F_{? ?}=10.5$, $\left.R^{2}=0.16, P<0.001\right)$ than by forest type (PerMANOVA, $\left.F_{?, ?}=6.8, R^{2}=0.10, P<0.001\right)$, or by the aridity (PerMANOVA, $F_{?, ?}=5.0, R^{2}=0.07, P<0.001$ ), as shown in the NMDS (Appendix S1: Fig. S5). The abundances of total fungi, saprotrophic fungi, ECM fungi, ammonia-oxidizing bacteria, and archaea were affected by soil depth; they were also significantly affected by the forest type (Appendix S1: Table S3). Even in subsurface soils, the total and ECM fungal abundances were higher in the oak forests, and ammonia-oxidizing bacterial and archaeal abundances were higher in the black locust forests. The predicted abundances of the prokaryotic potential to produce $\mathrm{N}$-degrading enzymes were not only affected by soil depth, but they were also significantly affected by the forest type (Appendix S1: Table S4). Even in subsurface soils, the prokaryotic potentials were still higher in the oak forests. 


\section{Discussion}

Consistent with our hypothesis, soil extractable $\mathrm{N}$ composition differed by forest type, regardless of the aridity gradient (Fig. 1). We found that EON content was higher and nitrate $\mathrm{N}$ content was substantially lower in the ECM forests, than in the AM forests. This is consistent with the pattern of extractable $\mathrm{N}$ composition reported previously (Fitzhugh et al. 2003, Phillips et al. 2013, Midgley and Phillips 2016). However, our findings suggest that the extractable $\mathrm{N}$ composition is more likely caused by mycorrhizal type than by soil physicochemical properties (Fig. 2). On the other hand, we found no differences in the ammonium $\mathrm{N}$ content between the ECM forests and AM forests, although some differences were previously reported (Fitzhugh et al. 2003, Phillips et al. 2013, Midgley and Phillips 2016). Furthermore, the soil microbial community corresponded to the extractable soil $\mathrm{N}$ composition: the abundances of nitrate $\mathrm{N}$ producers, ammonia-oxidizing bacteria and archaea, was consistently lower in the ECM forests than in the AM forests; consequently, the nitrate $\mathrm{N}$ content was also lower (Figs. 1 and 4). In contrast, the abundances of free-living EON producers and ammonium N producers, saprotrophic fungi, and prokaryotes, were not consistently lower in the ECM forests: their EON content was higher than in the AM forests, and they had similar ammonium $\mathrm{N}$ content (Figs. 1 and 3, Table 2).

Because ammonia-oxidizing prokaryotes are highly sensitive to soil moisture and $\mathrm{pH}$ (Gleeson et al. 2010, Chen et al. 2013, Marcos et al. 2016), we expected that ammonia-oxidizing prokaryotic abundance would not differ by forest type, and would differ more along the soil moisture and $\mathrm{pH}$ gradients. Nevertheless, ammonia-oxidizing prokaryotic abundance was consistently higher in the AM forest, regardless of the aridity gradient (Fig. 4), which suggests that ECM fungi affected the ammonia oxidizers. However, the lower abundance of free-living ammonia oxidizers in the ECM forests seemed not to result from the lack of $\mathrm{N}$ substrate for ammonia-oxidizing prokaryotes, because this substrate (ammonium $\mathrm{N}$ ) was sufficient in the ECM forests (Fig. 1). We propose two potential reasons for this: ECM fungi might directly limit the growth of ammonia oxidizers, by secreting inhibitory compounds, in order to monopolize the available $\mathrm{N}$, because ECM fungi are known to produce antimicrobial substances and can alter bacterial function and activity (Olsson et al. 1996, Frey-klett et al. 2005). Our laboratory incubation experiment revealed that net nitrification rate did not differ clearly between the forest types (Appendix S1: Fig. S1), implying that the inhibitory effects of ECM on ammonia oxidizers may have been removed by cutting and removing the roots before incubation. The second possibility is that even though the content is high, the ammonium $\mathrm{N}$ was not accessible to the ammonia-oxidizing prokaryotes, because of a reduced substrate diffusion and microbial mobility caused by drought (van Meeteren et al. 2008, Nguyen et al. 2018).
Moreover, if ECM fungi obtain ammonium $\mathrm{N}$ before ammonia-oxidizing prokaryotes can access it, these may limit the growth of ammonia-oxidizing prokaryotes, by limiting substrate availability, even when ammonium $\mathrm{N}$ content appears to be high.

In contrast to the nitrification step, the mineralization and the degradation steps appear not to be limited in the ECM forest. The fact that soil depth had a notable effect on soil saprotrophic fungal abundance and prokaryotic community structure (Appendix S1: Fig. S5, Table S3) suggests that substrate quantity and quality are important for the fungal and prokaryotic community structure. Further evidence to support this comes from another finding: by considering per unit $\mathrm{N}$ stocks, the differences between the AM and ECM forests, in terms of fungal saprotrophic abundance and prokaryotic Ndegrading gene abundance, ceased to exist. Substrate quality and quantity have been reported to be the primary factors affecting the soil fungal and prokaryotic community structure (Tian et al. 2017, Tatsumi et al. 2019). Interestingly, our findings do not provide strong support to back up previous reports, where ECM fungi limited saprotrophic growth (Gadgil and Gadgil 1971, Fernandez and Kennedy 2016). Nevertheless, we found that soil $\mathrm{C}$ content and $\mathrm{C}: \mathrm{N}$ ratio were higher in the

a) Conceptual mechanisms based on previous studies

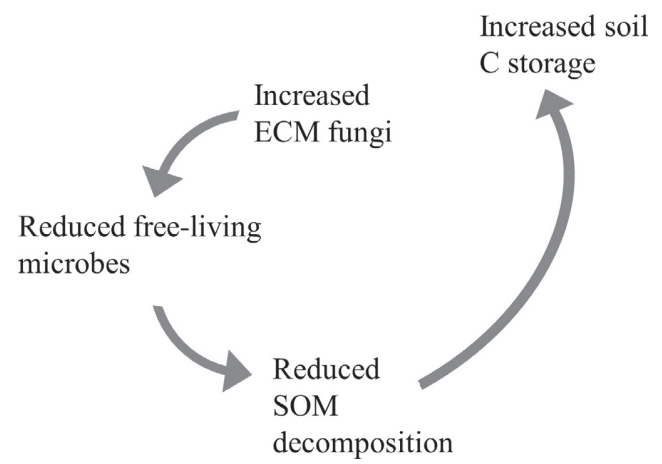

b) New conceptual mechanisms

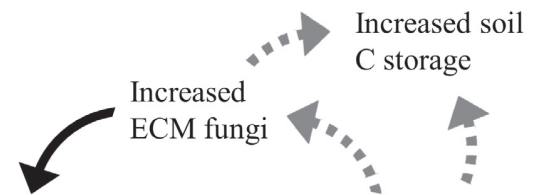

Reduced ammoniaoxidizing prokaryotes

Increased dependence

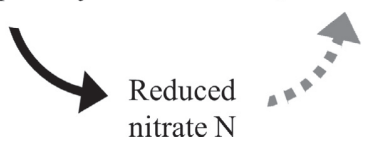

FIG. 5. Conceptual feedback mechanisms of ECM fungal function for soil $\mathrm{C}$ storage based on (a) previous literature (Orwin et al. 2011, Averill et al. 2014) and (b) results from this study. In panel b, the black arrows and the gray dashed arrows refer to the observed and predicted effects, respectively. 
ECM forest than in the AM forest; previous authors have attributed this pattern to the actions of ECM fungi (Orwin et al. 2011, Averill et al. 2014).

The EON content was somewhat higher in the ECM forests than in the AM forests (Fig. 1). Since the abundance of the expected primary producers of EON (the saprotrophic fungi) was not higher in the ECM forest (Fig. 3), other groups are likely to contribute to the high EON content in the ECM forest. Dominant ECM fungal taxa, especially the genus Cortinarius (the third most abundant ECM taxa in this study), have strong abilities to decay SOM (Bödeker et al. 2014). ECM fungal presence has been reported to raise the gross $\mathrm{N}$-depolymerization rate (Averill and Hawks 2016). It has also been reported and suggested that not all the mobilized $\mathrm{N}$ is transferred to the host plant by the ECM fungi (Näsholm et al. 2013, Pellitier and Zak 2018). Hence, it is possible for the ECM fungi to increase the input of the soil EON pool. In addition, EON content strongly declined with increasing soil depth, through a reduction in soil C:N ratio (Appendix S1: Fig. S4), suggesting that the SOM quality was also likely to be important in determining EON content. For further clarification, it would be useful to calculate the process rate (EON production rate) per unit abundance of the microbial drivers (ECM and saprotrophic fungi). This will require more detailed data, such as the gross transformation rate.

It remains unclear whether $\mathrm{N}$ competition is responsible for slowing SOM decomposition in the studied ECM forests, because total saprotrophic fungal abundance and prokaryotic potential to produce $\mathrm{N}$-degrading enzymes were not low in the ECM forests (Fig. 3, Table 2). We propose an alternative hypothesis, that $\mathrm{N}$ competition could also cause a high soil C storage (Fig. 5). The extremely low soil nitrate $\mathrm{N}$ content in the ECM forests is likely to make plants more dependent on ECM fungi for $\mathrm{N}$ acquisition (Hobbie and Hobbie 2008). In fact, we observed lower nitrate $\mathrm{N}$ content and higher ECM fungal abundance in wetter than in dryer ECM forest soils (Figs. 1 and 3). The increase in the plant dependence on ECM fungi can increase soil $\mathrm{C}$ in the form of microbial biomass, because ECM fungi have high microbial biomass (Högberg et al. 2002); such dependence can also increase plant $\mathrm{C}$ investment in ECM fungi in soils (Hobbie and Hobbie 2008, Näsholm et al. 2013). This is likely to contribute to high soil $\mathrm{C}$ storage, as previously suggested (Orwin et al. 2011, Averill et al. 2014). Although the relative contributions to soil $\mathrm{C}$ storage from these two functions of ECM fungi (slowing down SOM decomposition via competition with free-living microbes and increasing ECM dependence via competition with ammonia-oxidizing prokaryotes) may vary depending on the ecosystem, ECM fungi are likely to increase soil C storage more than AM fungi, via either or both of these mechanisms.

\section{ACKNOWLEDgments}

We would like to thank members of the Institute of Soil and Water Conservation of Chinese Academy of Science (CAS), the
Arid Land Research Center (ALRC) of Tottori University, and the Field Science, Education and Research Center (FSERC) of Kyoto University, for cooperation and logistics in both field surveys and laboratory analyses. We also greatly thank Kazuya Kobayashi and Takahito Yoshioka for helpful comments and Masataka Nakayama for helping with the laboratory analysis. This study was financially supported by JSPS-KAKENHI (Grant No. 15H05113), Grant-in-Aid for JSPS Research Fellow (Grant No. 17J07686), Japan-China Bilateral Joint Research Project of NSFC and JSPS (Grant No. 41411140035), and Fund of Joint Research Program of Arid Land Research Center, Tottori University.

\section{Literature Cited}

Averill, C., and C. V. Hawkes. 2016. Ectomycorrhizal fungi slow carbon cycling. Ecology Letters 53:1689-1699.

Averill, C., B. L. Turner, and A. C. Finzi. 2014. Mycorrhiza-mediated competition between plants and decomposers drives soil carbon storage. Nature 505:543-5.

Banning, N. C., L. D. Maccarone, L. M. Fisk, and D. V. Murphy. 2015. Ammonia-oxidising bacteria not archaea dominate nitrification activity in semi-arid agricultural soil. Scientific Reports 5:1-8.

Bates, D., M. Mächler, B. Bolker, and S. Walker. 2014. Fitting linear mixed-effects models using lme4. Journal of Statistical Software 67:1-48.

Bengtsson-palme, J., et al. 2013. Improved software detection and extraction of ITS1 and ITS2 from ribosomal ITS sequences of fungi and other eukaryotes for analysis of environmental sequencing data. Methods in Ecology and Evolution 4:914-919.

Bödeker, I. T. M., K. E. Clemmensen, W. de Boer, F. Martin, Å. Olson, and B. D. Lindahl. 2014. Ectomycorrhizal Cortinarius species participate in enzymatic oxidation of humus in northern forest ecosystems. New Phytologist 203:245-256.

Brzostek, E. R., D. Dragoni, Z. A. Brown, and R. P. Phillips. 2015. Mycorrhizal type determines the magnitude and direction of root-induced changes in decomposition in a temperate forest. New Phytologist 206:1274-1282.

Byrnes, J., M. Culbertson, B. Goodrich, and A. Kramer.2016. Package sem (Version 3.1-8). https://CRAN.R-project.org/ package $=$ sem

Chalot, M., and A. Brun. 1998. Physiology of organic nitrogen axquisition by ectomycorrhizal fungi and ectomycorrhizas. FEMS Microbiology Reviews 22:21-44.

Cheeke, T. E., R. P. Phillips, E. R. Brzostek, A. Rosling, J. D. Bever, and P. Fransson. 2016. Dominant mycorrhizal association of trees alters carbon and nutrient cycling by selecting for microbial groups with distinct enzyme function. New Phytologist 214:432-442.

Chen, Y., Z. Xu, H. Hu, Y. Hu, Z. Hao, Y. Jiang, and B. Chen. 2013. Responses of ammonia-oxidizing bacteria and archaea to nitrogen fertilization and precipitation increment in a typical temperate steppe in Inner Mongolia. Applied Soil Ecology 68:36-45.

Cornelissen, J., R. Aerts, B. Cerabolini, M. Werger, and M. van der Heijden. 2001. Carbon cycling traits of plant species are linked with mycorrhizal strategy. Oecologia 129:611-9.

Courty, P. E., M. Buee, A. G. Diedhiou, P. Frey-Klett, F. Le Tacon, F. Rineau, M. P. Turpault, S. Uroz, and J. Garbaye. 2010. The role of ectomycorrhizal communities in forest ecosystem processes: New perspectives and emerging concepts. Soil Biology \& Biochemistry 42:679-698.

Di, H. J., K. C. Cameron, J. P. Shen, C. S. Winefield, M. Ocallaghan, S. Bowatte, and J. Z. He. 2009. Nitrification driven by 
bacteria and not archaea in nitrogen-rich grassland soils. Nature Geoscience 2:621-624.

Drake, J. E., G.-B. Anne, K. S. Hofmockel, R. B. Jackson, K. S. Johnsen, J. Lichter, H. R. Mccarthy, M. Luke, P. Phillips, and J. S. Pippen. 2011. Increases in the flux of carbon belowground stimulate nitrogen uptake and sustain the long-term enhancement of forest productivity under elevated $\mathrm{CO}_{2}$. Ecology Letters 14:349-357.

Du, S., Y. Wang, T. Kume, J. Zhang, K. Otsuki, N. Yamanaka, and G. Liu. 2011. Sapflow characteristics and climatic responses in three forest species in the semiarid Loess Plateau region of China. Agricultural and Forest Meteorology 151:110.

Feral, C. J. W., H. E. Epstein, L. Otter, J. N. Aranibar, H. H. Shugart, S. A. Macko, and J. Ramontsho. 2003. Carbon and nitrogen in the soil-plant system along rainfall and land-use gradients in southern Africa. Journal of Arid Environments 54:327-343.

Fernandez, C. W., and P. G. Kennedy. 2016. Revisiting the "Gadgil effect": Do interguild fungal interactions control carbon cycling in forest soils? New Phytologist 209:1382-1394.

Fierer, N., A. S. Allen, J. P. Schimel, and P. A. Holden. 2003. Controls on microbial $\mathrm{CO}_{2}$ production: a comparison of surface and subsurface soil horizons. Global Change Biology 9:1322-1332.

Fierer, N., M. A. Bradford, and R. B. Jackson. 2007. Toward an ecological classification of soil bacteria. Ecology 88:1354 1364.

Fitzhugh, R. D., G. M. Lovett, and R. T. Venterea. 2003. Biotic and abiotic immobilization of ammonium, nitrite, and nitrate in soils developed under different tree species in the Catskill Mountains, New York, USA. Global Change Biology 9:1591-1601.

Frey-klett, P., M. Chavatte, M. Clausse, S. Courrier, C. Le Roux, J. Raaijmakers, M. G. Martinotti, J. Pierrat, J. Garbaye, and P. Frey-klett. 2005. Ectomycorrhizal symbiosis affects functional diversity of rhizosphere fluorescent pseudomonads. New Phytologist 165:317-328.

Gadgil, R. L., and P. D. Gadgil. 1971. Mycorrhiza and litter decomposition. Nature 233:133.

Gleeson, D. B., C. Müller, S. Banerjee, W. Ma, S. D. Siciliano, and D. V. Murphy. 2010. Response of ammonia oxidizing archaea and bacteria to changing water filled pore space. Soil Biology and Biochemistry 42:1888-1891.

Hobbie, E. A., and J. E. Hobbie. 2008. Natural abundance of ${ }^{15} \mathrm{~N}$ in nitrogen-limited forests and tundra can estimate nitrogen cycling through mycorrhizal fungi: a review. Ecosystems 11:815-830

Hodge, A., and K. Storer. 2014. Arbuscular mycorrhiza and nitrogen: implications for individual plants through to ecosystems. Plant and Soil 386:1-19.

Högberg, M. N., P. Högberg, and M. N. Högberg. 2002. Extramatrical ectomycorrhizal mycelium contributes one-third of microbial biomass and produces, together with associated roots, half the dissolved organic carbon in a forest soil. New Phytologist 154:791-795.

Homyak, P. M., S. D. Allison, T. E. Huxman, M. L. Goulden, and K. K. Treseder. 2017. Effects of drought manipulation on soil nitrogen cycling: a meta-analysis. Journal of Geophysical Research: Biogeosciences 122:3260-3272.

Isobe, K., N. Ohte, T. Oda, S. Murabayashi, W. Wei, K. Senoo, N. Tokuchi, and R. Tateno. 2015. Microbial regulation of nitrogen dynamics along the hillslope of a natural forest. Frontiers in Environmental Science 2:1-8.

Isobe, K., H. Oka, T. Watanabe, R. Tateno, R. Urakawa, C. Liang, K. Senoo, and H. Shibata. 2018. High soil microbial activity in the winter season enhances nitrogen cycling in a cool-temperate deciduous forest. Soil Biology and Biochemistry $124: 90-100$.

Iwaoka, C., S. Imada, T. Taniguchi, S. Du, N. Yamanaka, and R. Tateno. 2018. The impacts of soil fertility and salinity on soil nitrogen dynamics mediated by the soil microbial community beneath the halophytic shrub tamarisk. Microbial Ecology 75:985-996.

Jiao, F., X. Shi, F. Han, and Z. Yuan. 2016. Increasing aridity, temperature and soil $\mathrm{pH}$ induce soil C-N-P imbalance in grasslands. Scientific Reports 6:1-9.

Kanehisa, M., and S. Goto. 2000. KEGG: Kyoto Encyclopedia of genes and genomes. Nucleic Acids Research 28:27-30.

Kohler, A., et al. 2015. Convergent losses of decay mechanisms and rapid turnover of symbiosis genes in mycorrhizal mutualists. Nature Genetics 47:410-415.

Kowalchuk, G. A., and J. R. Stephen. 2001. Ammonia-oxidizing bacteria: a model for molecular microbial ecology. Annual Review of Microbiology 55:485-529.

Kuznetsova, A., P. B. Brockhoff, and R. H. B. Christensen. 2017. lmerTest package: tests in linear mixed effects models. Journal of Statistical Software 82:1-26.

Langille, M., et al. 2013. Predictive functional profiling of microbial communities using 16S rRNA marker gene sequences. Nature Biotechnology 31:814-21.

Li, Y. Y., and M. A. Shao. 2006. Change of soil physical properties under long-term natural vegetation restoration in the Loess Plateau of China. Journal of Arid Environments 64:77-96.

Li, Z., F. L. Zheng, and W. Z. Liu. 2012. Spatiotemporal characteristics of reference evapotranspiration during 1961-2009 and its projected changes during 2011-2099 on the Loess Plateau of China. Agricultural and Forest Meteorology 154-155:147-155.

Li, T., B. Ren, D. Wang, and G. Liu. 2015. Spatial variation in the storages and age-related dynamics of forest carbon sequestration in different climate zones - evidence from black locust plantations on the loess plateau of China. PLoS ONE 10:e0121862.

Lindahl, B. D., and A. Tunlid. 2015. Ectomycorrhizal fungi potential organic matter decomposers, yet not saprotrophs. New Phytologist 205:1443-1447.

Lü, H., D. Liu, and Z. Guo. 2003. Natural vegetation of geological and historical periods in Loess Plateau. Chinese Science Bulletin 48:7-9.

Marcos, M. S., M. B. Bertiller, H. S. Cisneros, and N. L. Olivera. 2016. Nitrification and ammonia-oxidizing bacteria shift in response to soil moisture and plant litter quality in arid soils from the Patagonian Monte. Pedobiologia 59:1-10.

Midgley, M. G., and R. P. Phillips. 2016. Resource stoichiometry and the biogeochemical consequences of nitrogen deposition in a mixed deciduous forest. Ecology 97:3369-3377.

Moore, J. C., K. McCann, H. Setälä, and P. C. De Ruiter. 2003. Top-down is bottom-up: Does predation in the rhizosphere regulate aboveground dynamics? Ecology 84:846-857.

Näsholm, T., P. Högberg, O. Franklin, D. Metcalfe, S. G. Keel, C. Campbell, V. Hurry, S. Linder, and M. N. Högberg. 2013. Are ectomycorrhizal fungi alleviating or aggravating nitrogen limitation of tree growth in boreal forests? New Phytologist 198:214 221.

Nguyen, N. H., Z. Song, S. T. Bates, S. Branco, L. Tedersoo, J. Menke, J. S. Schilling, and P. G. Kennedy. 2016. FUNGuild: An open annotation tool for parsing fungal community datasets by ecological guild. Fungal Ecology 20:241-248.

Nguyen, L. T. T., Y. Osanai, I. C. Anderson, and B. K. Singh. 2018. Flooding and prolonged drought have differential legacy impacts on soil nitrogen cycling, microbial communities and plant productivity. Plant and Soil 431:371-387.

Nicol, G. W., S. Leininger, C. Schleper, and J. I. Prosser. 2008. The influence of soil $\mathrm{pH}$ on the diversity, abundance and 
transcriptional activity of ammonia oxidizing archaea and bacteria. Environmental Microbiology 10:2966-2978.

Oksanen, A. J., et al. 2016.Package vegan (Version 2.4-0). https://CRAN.R-project.org/package=vegan

Olsson, P. A., M. Chalot, B. Erland, R. D. Finlay, and B. Saderstriim. 1996. Ectomycorrhizal mycelia reduce bacterial activity in a sandy soil. FEMS Microbiology Ecology 21:77-86.

Orwin, K. H., M. U. F. Kirschbaum, M. G. St John, and I. A. Dickie. 2011. Organic nutrient uptake by mycorrhizal fungi enhances ecosystem carbon storage: a model-based assessment. Ecology Letters 14:493-502.

Otsuki, K., N. Yamanaka, S. Du, F. Yamamoto, Z. Xue, S. Wang, and Q. Hou. 2005. Seasonal changes of forest ecosystem in an artificial forest of Robinia pseudoacacia in the Loess Plateau in China. Journal of Agricultural Meteorology 60:613-616.

Pellitier, P. T., and D. R. Zak. 2018. Ectomycorrhizal fungi and the enzymatic liberation of nitrogen from soil organic matter: why evolutionary history matters. New Phytologist 217:68-73.

Phillips, R. P., E. Brzostek, and M. G. Midgley. 2013. The mycorrhizal-associated nutrient economy: a new framework for predicting carbon-nutrient couplings in temperate forests. New Phytologist 199:41-51.

Phillips, L. A., V. Ward, and M. D. Jones. 2014. Ectomycorrhizal fungi contribute to soil organic matter cycling in subboreal forests. ISME Journal 8:699-713.

Qiu, L., F. Zheng, and R. Yin. 2012. SWAT-based runoff and sediment simulation in a small watershed, the loessial hillygullied region of China: capabilities and challenges. International Journal of Sediment Research 27:226-234.

R Core Team. 2014. R: A language and environment for statistical computing. R Foundation for Statistical Computing, Vienna, Austria.

Read, D. J., and J. Perez-Moreno. 2003. Mycorrhizas and nutrient cycling in ecosystems - a journey towards relevance? New Phytologist 157:475-492.

Reichmann, L. G., S. E. Osvaldo, and D. P. C. Peters. 2013. Water controls on nitrogen transformations and stocks in an arid ecosystem. Biogeosciences 4:1-17.

Saiya-Cork, K., R. Sinsabaugh, and D. Zak. 2002. The effects of long term nitrogen deposition on extracellular enzyme activity in an Acer saccharum forest soil. Soil Biology and Biochemistry 34:1309-1315.

Sinsabaugh, R. L., et al. 2008. Stoichiometry of soil enzyme activity at global scale. Ecology Letters 11:1252-1264.

Smith, S. E., and D. Read. 2008. Mycorrhizal symbiosis. Third edition. Academic Press, Cambridge, UK.

Smith, S. E., and F. A. Smith. 2011. Roles of arbuscular mycorrhizas in plant nutrition and growth: new paradigms from cellular to ecosystem scales. Annual Review of Plant Biology 62:227-50.

Stempfhuber, B., et al. 2015. $\mathrm{pH}$ as a driver for ammonia-oxidizing archaea in forest soils. Microbial Ecology 69:879-883.

Sterkenburg, E., K. E. Clemmensen, A. Ekblad, R. D. Finlay, and B. D. Lindahl. 2018. Contrasting effects of ectomycorrhizal fungi on early and late stage decomposition in a boreal forest. ISME Journal 12:2187-2197.

Suzuki, M. T., and S. J. Giovannoni. 1996. Bias caused by template annealing in the amplification of mixtures of $16 \mathrm{~S}$ rRNA genes. Applied and Environmental Microbiology 62:2-8.

Talbot, J. M., S. D. Allison, and K. K. Treseder. 2008. Decomposers in disguise: Mycorrhizal fungi as regulators of soil $\mathrm{C}$ dynamics in ecosystems under global change. Functional Ecology 22:955-963.

Tatsumi, C., T. Taniguchi, S. Du, and N. Yamanaka. 2019. The steps in the soil nitrogen transformation process vary along an aridity gradient via changes in the microbial community. Biogeochemistry 144:15-29.

Thoms, C., A. Gattinger, M. Jacob, F. M. Thomas, and G. Gleixner. 2010. Direct and indirect effects of tree diversity drive soil microbial diversity in temperate deciduous forest. Soil Biology and Biochemistry 42:1558-1565.

Tian, Q., T. Taniguchi, W. Shi, G. Li, and N. Yamanaka. 2017. Land-use types and soil chemical properties influence soil microbial communities in the semiarid Loess Plateau region in China. Scientific Reports 7:1-9.

Toju, H., A. S. Tanabe, S. Yamamoto, and H. Sato. 2012. Highcoverage ITS primers for the DNA-based identification of Ascomycetes and Basidiomycetes in environmental samples. PLoS ONE 7:e40863.

van Meeteren, M. J. M., A. Tietema, E. E. van Loon, and J. M. Verstraten. 2008. Microbial dynamics and litter decomposition under a changed climate in a Dutch heathland. Applied Soil Ecology 38:119-127.

Wang, Y., and P. Qian. 2009. Conservative fragments in bacterial 16S rRNA genes and primer design for 16S ribosomal DNA amplicons in metagenomic studies. PLoS ONE 4:e7401.

Wang, B., and Y. Qiu. 2006. Phylogenetic distribution and evolution of mycorrhizas in land plants. Mycorrhiza 16:299-363.

Yang, Y., M. Tang, R. Sulpice, H. Chen, S. Tian, and Y. Ban. 2014. Arbuscular mycorrhizal fungi alter fractal dimension characteristics of Robinia pseudoacacia L. seedlings through regulating plant growth, leaf water status, photosynthesis, and nutrient concentration under drought stress. Journal of Plant Growth Regulation 33:612-625.

Yamanaka, N., Q. Hou, and S. Du. 2014. Vegetation of the Loess Plateau. Pages 49-60 in A. Tsunekawa, G. Liu, N. Yamanaka and S. Du, editors. Restoration and Development of the Degraded Loess Plateau. Springer, China.

Zak, D. R., et al. 2019. Exploring the role of ectomycorrhizal fungi in soil carbon dynamics. New Phytologist 223:33-39.

Zhang, J., T. Taniguchi, R. Tateno, M. Xu, S. Du, G. Bin Liu, and N. Yamanaka. 2013. Ectomycorrhizal fungal communities of Quercus liaotungensis along local slopes in the temperate oak forests on the Loess Plateau, China. Ecological Research 28:297-305.

Zimmerman, A. E., A. C. Martiny, and S. D. Allison. 2013. Microdiversity of extracellular enzyme genes among sequenced prokaryotic genomes. ISME Journal 7:1187-1199.

\section{SUPPORTING INFORMATION}

Additional supporting information may be found in the online version of this article at http://onlinelibrary.wiley.com/doi/ 10.1002/ecy.2963/suppinfo

\section{Data Availability Statement}

Sequence data are available on the NCBI Sequence Read Archive under accession numbers DRA008376 and DRA008550. 